Journal of Comparative International Management

\title{
Corruption and Management of Capacity Building in Developing and Emerging Countries A Critical Overview
}

\section{Joanna Brzezińska, Elie Chrysostome and Jan Gola}

\section{Volume 21, Number 1, 2018}

URI: https://id.erudit.org/iderudit/1062483ar

DOI: https://doi.org/10.7202/1062483ar

See table of contents

Publisher(s)

Management Futures

ISSN

1481-0468 (print)

1718-0864 (digital)

Explore this journal

Cite this article

Brzezińska, J., Chrysostome, E. \& Gola, J. (2018). Corruption and Management of Capacity Building in Developing and Emerging Countries: A Critical Overview. Journal of Comparative International Management, 21(1), 9-26. https://doi.org/10.7202/1062483ar

\section{Article abstract}

We examined the phenomenon of corruption in social and economic life in Poland and found that corruption effectively undermines the functioning of the state by destabilizing the economy. One of our major findings was gross deception in project proceedings for contractor selection in major public investment sectors, for the benefit of the contractors. This type of corruption led to the de-concentration and de-specialisation of the corrupt individuals. They were forced to keep double books and bear the costs of keeping illegal transactions secret for as long as possible. This resulted in a decline of economic growth for the state. We also found abuses by private entrepreneurs in the infrastructure and legislative areas. They committed bribery to advance their own economic interests, often worth millions of dollars. These activities have suppressed the growth of states by reducing the number of investments, mismanaging natural resources, and blocking essential structural reforms. However, these pathologies were present not only in Poland but worldwide. 


\title{
Corruption and Management of Capacity Building in Developing and Emerging Countries: A Critical Overview
}

\author{
by \\ Joanna Brzezińska \\ University of Wroclaw, Poland \\ Elie Chrysostome \\ State University of New York at Plattsburgh, U.S.A. \\ Jan Gola \\ University of Wroclaw, Poland
}

\begin{abstract}
We examined the phenomenon of corruption in social and economic life in Poland and found that corruption effectively undermines the functioning of the state by destabilizing the economy. One of our major findings was gross deception in project proceedings for contractor selection in major public investment sectors, for the benefit of the contractors. This type of corruption led to the de-concentration and de-specialisation of the corrupt individuals. They were forced to keep double books and bear the costs of keeping illegal transactions secret for as long as possible. This resulted in a decline of economic growth for the state. We also found abuses by private entrepreneurs in the infrastructure and legislative areas. They committed bribery to advance their own economic interests, often worth millions of dollars. These activities have suppressed the growth of states by reducing the number of investments, mismanaging natural resources, and blocking essential structural reforms. However, these pathologies were present not only in Poland but worldwide.
\end{abstract}

\section{Introduction}

This paper examines the phenomenon of corruption in social and economic life. Corruption erodes the basic fabric of civic society and is destructive to basic moral codes such as honesty, loyalty, and accountability. Persistent corruption effectively undermines the functioning of the state by destabilizing the economy. This paper presents the negative effects of active and passive corruption on the economy and considers some of the legal mechanisms that can be used to curtail such destructive phenomena. It was also noted that while choosing contractors in major public investment sectors, the proceedings were misrepresented by some contractors for their own economic interests. This type of corruption led to the de-concentration and de-specialisation of the corrupt individuals, as they were forced to keep double books and bear the costs of keeping illegal transactions secret for as long as possible. The cumulative effect was the decline of economic growth for the state.

The infrastructure sectors, such as energy, telecommunications, aviation, and railway transportation, are adversely affected by corruption. These are vital areas, and investments in them are necessary for both developing and developed countries. Misuse of these funds exacerbate the threats already present in the country such as giving concessions, licenses, and permits to unqualified contractors. Other threats are related to the legislative process such as the development of laws governing infrastructural sectors. Abuse in the legislative process by contractors, and the bribes paid by private entrepreneurs to advance their own economic interests often amounting to millions of dollars are two of the huge crimes crippling states' economies. For example, when corruption suppresses growth, it reduces 
the number of private investments in the state. This means excessive burden on the private sector, poor management of natural resources, and blockage of essential structural reforms.

The paper is organized as follows. Section two describes the concept of corruption and its perverse effects on the economy and society. In sections three and four, we examine how corruption contributes to weakening institutions for capacity building. Anti-corruption strategies for capacity building are then discussed in section five. We then summarize our key findings and policy recommendation in section six of the paper.

\section{The Concept of Corruption and its Perverse Effects}

\subsection{Concept and Theories of Corruption}

\subsubsection{Concept}

Corruption has existed in Poland since the introduction of the division between the public and private sphere (Góral, 2004). Corruption blurs the line between private and public property. For instance, persons holding public offices take bribes. Entrepreneurs enter into informal arrangements with public officials in order to benefit from them (Kojder, 2002). As a result of these illegal activities, public services often turn into private businesses.

Corruption is commonly identified with decay, destruction, demoralisation, and a weakening sense of morality in a society. However, it has no single definition. At the most basic level, corruption is construed as the abuse of public office for personal gain. Corruption is defined as the abuse of a public function to obtain private benefits. These offences are rarely prosecuted since most of them are practically traceless.

One of the key features of corruption is its widespread nature. Because of its dynamic nature, corruption can evolve at various stages and manifest itself in the form of numerous scandals (Kurczewski, 2001). It exists in all economic and political systems, all around the world. What is more, its existence is characterised by entropy, as it spreads to the areas from which it was absent before. In this sense, corruption has no boundaries. It crosses all cultural and ideological borders (Kojder, 2002).

In general, corruption is promising, offering, giving, demanding, and accepting by a person, directly or indirectly, any undue material gain, personal or of any other nature, for oneself or for another person; or accepting an offer or promise of getting such a material gain in return for a specific action or omission in the course of performing a public function or conducting a business activity. Corruption can be further defined as accepting an offer or promise in return for an act, or omission of an act, in the course of performing a public duty assigned by a public office, including the performance of obligations vis-a-vis public authorities (institutions). These are infringements of public trust and a socially detrimental reciprocity (Central Act - Corruption Bureau Act, 2006).

\subsubsection{Theories}

A major factor contributing to the growth of corruption is arbitrariness. Excessive discretion and superfluous authority vested in clerks and public officers can contribute to the escalating scale of this criminal activity. Corruption undermines trust in the law and state authorities. It brings about an increase in the price of goods, services, commercial transactions, and shakes citizens' sense of security. Corruption destroys the basic value system of a society. 
It is crucial to identify the areas of public activity where corruption is particularly widespread. Corruption seems to be everywhere: healthcare centres, banks, fiscal administration, customs administration, and local government units. The highest risk of this pathological practice seems to be in the areas of customs administration, public assets management, special purpose funds, the public procurement system, and licensing business activities (Kojder, 2002). Because of the discretion granted to officials, there is a risk of a conflict of interest, and, subsequently, corruption. On the other hand, if the public sphere is functioning well, there is no social acceptance of corruption and as long as the social contract remains valid, corruption is rejected (Koryś, 2006).

The economic perspective makes it possible to determine corruption's role in the variable results achieved on the competitive market. Higher market uncertainty caused by existing corruption decreases the average level of national gross investments in states affected by high corruption by $20 \%$, as compared to states where corruption levels are low (Płoskonka, 2008). What is more, corruption has a detrimental effect on the volume of sales by businesses, and is a huge contributing factor to poverty and poor living conditions (Płoskonka, 2008).

The persistence of corruption in the economy runs up the costs of investment and manufacturing, resulting in a decline of economic growth (Tarchalski, 2000). Corruption suppresses the growth of a state by reducing the number of private investments, creating excessive burden on the private sector, poor management of natural resources, and creating a high demand for essential structural reforms (Płoskonka, 2008).

As Dunphy (1999) points out, corruption is one of the strongest factors impeding private investments. Corruption in the investment process creates a situation where projects become excessively complex and simply unprofitable to execute. This means the more time the projects take to complete, the more bribes are required. Often the bigger the project, the bigger the bribe and the higher the transaction costs (Tarchalski, 2000).

However, this study also revealed some neutral or even positive effects of corruption on some projects. For example, it was found that some cases of bribery had helped reduce the transaction costs of the projects in overly regulated, irrational, or excessively bureaucratic environments. This was especially true at the early stages of development of states' laws governing project proceedings. Aidt (2009) emphasises that "The general idea is that corruption facilitates beneficial trades that would otherwise not have taken place. In doing so, it promotes efficiency by allowing individuals in the private sector to correct pre-existing government failures of various sorts.”

Nonetheless, it is important to emphasize that in the long run the effect of bribery is destructive (Tymiński, 2006). A market characterised by systemically rooted corruption is perceived by serious investors as less attractive due to the need to bear extra costs resulting from institutionalised bribery (Tymiński, 2006).

Moreover, corruption has a huge negative impact on the trade balance of states. For example, we found outflows outweighing inflows in the states we observed because investors looked for safer places to deposit their funds (Gola, 2013). In addition, we found revenues on exports were lower than they could be, because the price level established in negotiations had been affected by corruption. This made the revenue earned from trade below the global average (Kurczewski, 2000).

Globalisation, accelerating since the end of the 20th century, has internationalised corruption (Kurczewski, 2000) by providing more opportunities for some groups and less for others. This helped some groups grow economically strong with more scope and privileges for them. Such privileged groups are rewarded based on global competitiveness, but not on state competitiveness. This has created an 
uneven distribution of economic opportunities among states. If privileges are available only to a group of people in one state, in the long run the state will become uncompetitive globally and will need to be abolished (Kurczewski, 2000).

S. Rose-Ackerman differentiates between two situations concerning corruption from the economic perspective. The first one applies to a fixed supply and the second to a variable supply. When the corruption market is effective, services are provided to those who are willing to pay the most. If no price discrimination takes place, the bribe "balancing the market" is equal to the price on the effective market. The state could sell the service legally with the same effect. This shows that bribes boost the income of the state officials, but do not increase state revenues. When competition exists both on the corruption market and the labour market, illegal bribes become similar to the market prices. People willing to give the biggest bribe are successful, while those who play by the rules lose (RoseAckerman, 2001).

The second situation is related to the variable supply. When the quantity of specific goods is limited or variable, an official can distribute less goods than officially planned, in order to increase the economic benefits for distribution. The situation is quite different when the state establishes the level of supply below the monopoly threshold and corrupt officials try to increase the supply. This situation is just like a private monopoly. The aim here is not to optimize the services provided to the public, but to maximize one's own profits (Rose-Ackerman, 2001). In such a case, the official's conduct is not only dependent on the sum of their economic benefits, but also on the volume of income that can be generated as a result of cooperation with the bribes who are the beneficiaries of the officials (Gola, 2013).

In social sciences, corruption is often perceived as the use of public authority for private gains. Hence, it takes place in a situation where a public office is used to get private gains (Nowak, 2009). Corruption is present in every society and in every economic system. There is no doubt that this pathology increases and reinforces social inequalities. It petrifies social structures by rewarding a specific position and status.

\subsection{Perverse Effects of Corruption}

The World Bank's research shows that corruption is not related to the national characteristics of a given society (Czaputowicz, 2008). It is said to be a symptom of structural flaws of the political and economic system, resulting from the malfunctioning of public institutions. Hence, it cannot be concluded that the Polish are more susceptible to corruption than other societies (Czaputowicz, 2008).

Corruption is present in both conservative and democratic societies where change is resisted or happens too quickly. According to K. Tarchalski, “...in societies based on national loyalty, including many those of numerous post-colonial countries, corruption develops because the idea of public interest has not been rooted there, yet." In his opinion, a fast process of modernisation is also "characterised by intensive presence of corruptive practices, because too many values, norms, institutions and individual lives are affected by the changes over too short a period of time.” (Tarchalski, 2000).

Corruption limits social mobility and, consequently, the transparency of market relationships based on it. It should be noted that corrupt environments reinforce or increase existing social relations. They expand the powers of the people positioned at the top of the political hierarchy, including implied power and the ability to utilize blackmail. However, even a change of the system does not result in a change of the existing social inequalities (Tarchalski, 2000). It is noted that lack of trust in societies caused by corruption leads to the revival of neo-tribal culture and group loyalty. Its aim is to divide and to disintegrate society. The common characteristic of all corrupt practices is their secrecy from the public (Urbańska, 2003). 
One of the major issues in preventing corruption are the psychological factors determining the dynamics of the phenomena observable in criminal practices (Obuchowski, 1983). It should be noted that the pathology of corruption as it relates to individuals results mainly from economic crimes (Wrightsman, 1987). It could be described as a situation where "it doesn't pay" to be honest, particularly when the costs of breaching a norm are lower than the costs of abiding by them (Hoyst, 2004). One of the factors affecting a decision to commit an act of infringement on established norms is the relationship between the possible punishment and expected reward. A sense of impunity is an important element encouraging people to take actions in breach of established norms. This may be based upon confidence in the success of one's actions and a belief in the impotence of existing social controls (Hołyst, 2004).

It is emphasised that the essence of pathology in economic life is the abuse of trust. After all, proper functioning of any economic system depends on mutual trust of various entities forming the system. Without trust, the process of exchange and production is not possible; nor are any long-term actions, investments, or loans. When fraud takes place, everyone immediately wants to protect themselves against such practices. Everyone starts to be perceived as a likely wrongdoer, which, in time, leads to the degradation of economic life (Hołyst, 2004). M. O'Donnell emphasises that “...the political consequences of corruption are more difficult to quantify. It is generally accepted that growing perceptions of corruption diminish trust in public institutions. Only recently, however, have scholars identified perceptions of corruption as one of the key determinants of legitimacy and regime support in multi-country analyses. State corruption has buttressed support for military governments in Pakistan, Uganda, Nigeria, and elsewhere, undermining demilitarization.” (O’Donnell, 2006).

\section{Corruption is the Result of Weak Capacity Building Institutions}

\subsection{Systems}

The economic and public administration systems do not achieve anything without a wellfunctioning staff, and facilitating this should be perceived as a priority. The objectivity of public administration employees affects their functioning. The practical application of this principle in the public administration is guaranteed by the concept of incompatibilities. It refers to the limitation or exclusion of persons holding public office from involvement in various legal or contractual situations. This concept is applied in democratic law-governed states, and those in public office are required to accept them.

S. Rose-Ackermann emphasises, "All political systems need to mediate the relationship between private wealth and public power. Those that fail risk a dysfunctional government captured by wealthy interests. Corruption is one symptom of such failure with private willingness-to-pay trumping public goals. Private individuals and business firms pay to get routine services and to get to the head of the bureaucratic queue. They pay to limit their taxes, avoid costly regulations, obtain contracts at inflated prices, and get concessions and privatized firms at low prices. If corruption is endemic, public officials, both bureaucrats and elected officials, may redesign programs and propose public projects with few public benefits and many opportunities for private profit.” (Rose-Ackermann, 2004).

Szapiel (2012) emphasises that lawfulness of the state is of utmost importance in a modern institutional economy. Her opinion is that the practical realisation will only happen when the lawgoverned democratic state calls for strengthening the constitutional constraints based on the democratic system. To prevent corruption as much as possible, not only in developing countries but also in developed ones, she suggests paying attention to the following areas:

- proper designing and management of the state organisation, free of corruption pathologies, characterised by transparency and impartiality of operation; 
- proper designing and implementation of the principles characterising law-governed democratic states where public administration bodies operate on the basis of generally binding mandatory provisions of law;

- developing social attitudes which perceive corruption as a negative phenomenon.

Szapiel (2012) also discusses some of the positive and negative impacts of corruption on the state organisation and its functioning. Positive impacts include the satisfaction of the needs of citizens, enabling ongoing social control, and review of institutions by the public - which is more established in developed than in developing countries. An example of adverse effects are the paralysis of functioning of some state bodies or occurrence of other negative phenomena (Szapiel, 2012). According to her, "empirical research conducted by representatives of new political economy proves the theses on imperfection of democracy and on priority importance of the rule of law. Economies in the states which have created favourable conditions for political stability and where the rule of law model of governing prevails develop faster, regardless of a political regime.”

The transparency mentioned above is related to the adequate functioning of the access to public information principle. It is an effective method for obtaining reliable and objective knowledge of the functioning of public institutions in democratic political systems. Therefore, transparency of the public good is particularly important for public offices. It is the obligation of public offices to submit statements on private assets. All entities must submit such statements to reduce corruption in the operation of public administration bodies.

Szapiel (2012) emphasises that lawfulness of the state is of utmost importance in modern institutional economy. She maintains that practical realisation of the law-governed democratic state requires calling for strengthening constitutional constraints in the democratic system. It is the only system where citizens have adequate control over such matters.

\subsection{Strength}

It should be noted that the strength of a state is its institutional potential. Our study found that the number of strong states is relatively small. According to the state strength index developed by the Economist Intelligence Unit (EIU), only 34 countries were classified as very strong, another 34 states as moderate, 33 as weak, and 58 as very weak states. This shows a huge number of countries are weak states, being "in fact, shadows of economic globalisation” (Szapiel, 2012).

\subsection{Structure}

Economists claim that the introduction of institutional mechanisms within a supra-national structure should consider facilitating the operation through:

- adoption of voting rules within a supra-national political structure,

- adoption of representation rules in a supra-national political structure: it is difficult to make decisions or conduct negotiations when at least a hundred nations are interested in the issue in question,

- adoption of transparency rules in a supra-national political structure - particularly important is the transparency based on well-established formal institutions guaranteeing to all states equal access to information and adopted resolutions;

- adoption of dispute resolution rules - their purpose is not only to increase trust and strengthen the authorisation to exercise global management, but also to enable finding solutions that better account for the interests of all states; 
- streamlining the procedures for finding satisfactory solutions and accountability procedures applicable to state representatives, and

- appointment of a coordinator in a supra-national political structure in order to ensure better global enforcement of rule of law principles” (Szapiel, 2012).

\section{Strategies for Anti-Corruption Capacity Building}

\subsection{Anti-Corruption Agency}

The research carried out by many international and national organisations confirmed that Poland is a country at high risk of corruption. The existing legal solutions aimed at combating and preventing corruption in public administration have not worked. Administrative law tools aimed at reducing corruption in Poland are not effective in reforming the situation. Even though most of the criminal law provisions are compliant with international law following the amendments of 2003, certain reservations may be raised with respect to the Central Anti-Corruption Bureau, which, pursuant to the claims of its creators, is modelled upon the premises promoted by the European Anti-Fraud Office (OLAF).

Article 1 of the Central Anti-Corruption Bureau Act provides that the Bureau is a special service dedicated to combating corruption in public and economic law, in particular in state and local government institutions. The Act was developed to prevent practices detrimental to the economic interests of the state (Central Act - Corruption Bureau Act). Its tasks include identifying, preventing, and disclosing offences against state institutions and local authorities, judiciary, elections and referendums, public order and authenticity of documents, property, business transactions, trade in money and securities, political party financing, fiscal duties, and settlements of subsidies and grants, as long as such offences arise in connection with corruption or activity detrimental to the economic interests of the state (Siwik, 2009).

What is more, the Central Anti-Corruption Bureau deals with identifying and preventing cases of non-compliance with anti-corruption law in the public administration sector and disclosing cases of noncompliance with legal procedures governing the process of decision-making and implementation in the field of privatisation and commercialisation, financial assistance, public procurement, management of local authorities' assets and the granting of licenses, permits, subject and object related exemptions, breaks, preferences, quotas, tariff ceilings, sureties, and loan guaranties.

However, it is also important to note that controls on the correctness and accuracy of property declarations for business activities should be undertaken by public officials, not by the Bureau. Furthermore, one should also mention that, unlike OLAF, this authority has not been vested with special guaranties of independence. It is managed by the head of the Central Anti-Corruption Bureau appointed by the President of the Council of Ministers (who also acts as the supervisor of the unit), which is highly controversial. In 2009, the operations of the first Head of the Bureau came under fire. The Head was dismissed by the President of the Council of Ministers in connection with the use of the anti-corruption agency for political purposes and indulging in false allegations and lies. Pursuant to the Act, the Prime Minister dismissed the Head of the Bureau, having consulted the President, Social Services Council, and the Parliamentary Special Services Commission at the Polish Sejm. Unfortunately, this was not the only weakness of the Bureau. For instance, other critics pointed to the lack of the agency's exclusive competence in its field of operational activity and investigations concerning corruption, and its failure to include prevention and education in its list of duties. 


\subsection{The Various Legal Systems}

It is important to bear in mind that one of the key factors contributing to corruption is the process of applying administrative law to a public administration authority. The pathology of corruption is the social mistrust in the state and public authorities (Gola \& Olszewski, 2010). The credibility of the entities granting licenses to perform specific business activities in the sector is of key importance.

Legislators should ensure that competitive procedures applied in the infrastructural sectors are fair. The criteria for issuing an administrative decision should be laid down clearly (Szydło, 2005). All entrepreneurs participating in the procedure should be treated equally and the selection process should be fair. It is unacceptable to differentiate any entrepreneur on any discriminatory basis, and the concession holder should be neutral (Horubski, 2007).

It is also important to make a clear distinction between corruption and lobbying. Lobbying is perceived as positive as long as it is conducted in compliance with law, but corruption is not. Lobbying activities can generate significant benefits to the economy, but corruption supresses growth by reducing public investments (Aernoudt, 2003).

\subsection{Regional Legal Systems}

An extremely important EU legal act worth mentioning in the discussion on corruption is the Convention on the fight against corruption involving officials of the European Communities or officials of Member States of the European Union, signed on the 26th of May, 1997. It pertains to activities detrimental to the financial interests of the European Union. The treatment of corrupt practices as criminal acts, adopted in the Convention, has proved necessary because the criminal law of the individual Member States did not work. When a crime was committed by a foreign official or an official employed by a supra-national organisation (Garus-Ryba, 2000),.. internal definitions concerning public officials usually pertained to domestic situations. This had negative consequences arising from the fact that corruption of a foreign or community official was not treated in domestic legislation as a criminal act, even if the criminal act was committed in the state concerned or by that state's citizen (Srebro, 2004).

The Convention does not provide for criminal liability of legal persons for active or passive corruption. Yet, Article 6 thereof envisages criminal liability of heads of businesses. It states that "each Member State shall take the necessary measures to allow heads of businesses or any persons having power to take decisions or exercise control within a business to be declared criminally liable in accordance with the principles defined by its national law in cases of corruption, as referred to in Article 3 , by a person under their authority acting on behalf of the business." Some people claim that the Convention is a kind of substitute for criminal liability of legal persons. However, it can be said to serve a similar preventive purpose to criminal liability of legal persons. It is intended to force businesses to fight against corruption in their territory, to adopt codes of ethics, and apply transparent procedures (Nowak, 2009).

To some degree, corruption is also addressed in the Second Protocol to the Convention on the protection of the European Communities' financial interests signed on June 19, 1997, in Brussels. It obligates Member States to establish money laundering as a criminal offence. It contains provisions that considerably amend the Convention itself and its First Protocol, pertaining to criminal liability of the legal persons. It imposes an obligation to hold liable any legal person for fraud, active corruption, and money laundering committed for their own benefit or as part of a group. Such acts shall be punishable if they satisfy the criteria laid down in the above-mentioned documents and damage the European Communities' financial interests (Nowak, 2009). 


\subsection{National Legal System}

In Polish criminal law, corruption is defined as a pathology. Corruption has been classified into several categories representing prohibited acts sanctioned with penalties in the Criminal Code, which includes:

- passive bribery, referred to as corruptibility related to the performance of public functions (Article 228 Criminal Code),

- active bribery, also referred to as corruption (Article 229 Criminal Code),

- paid favouritism, defined as agency in settling a specific matter in exchange for a proprietary or personal benefit relying on influence in state or local institutions, etc., or the use of such agencies (Articles 230 and 230a CC),

- public officer's abuse of rights or failure to meet duties in order to obtain a proprietary or personal benefit (Article 231(2) CC),

- bribery and corruptibility in the electoral context, defined as casting a specific vote in exchange for a proprietary or personal benefit or requesting or granting such a benefit (Article 250a CC),

- demanding or accepting a proprietary or personal benefit or a promise of such a benefit in exchange for an abuse of rights or failure to meet a duty by an officer managing an organisational unit running a business activity and hired under an employment contract, mandate contract, or contract for a specific work (Article 296a CC),

- corruption-related offences in the context of insolvency and bankruptcy,

- accepting or awarding proprietary benefits in exchange for actions detrimental to creditors (Article 302(2) and 302(3) Criminal Code),

- preventing or hindering a public tender in order to obtain a proprietary benefit, and acting in cooperation with another person to the detriment of the owners of property or a person or institution awarding the contract in the tender (Article 305(1) CC) (Mapa Korupcji, CBA).

The chart below aims to present the type and scale of criminal conduct classified as corruption in Poland in the period 2004-2010. 


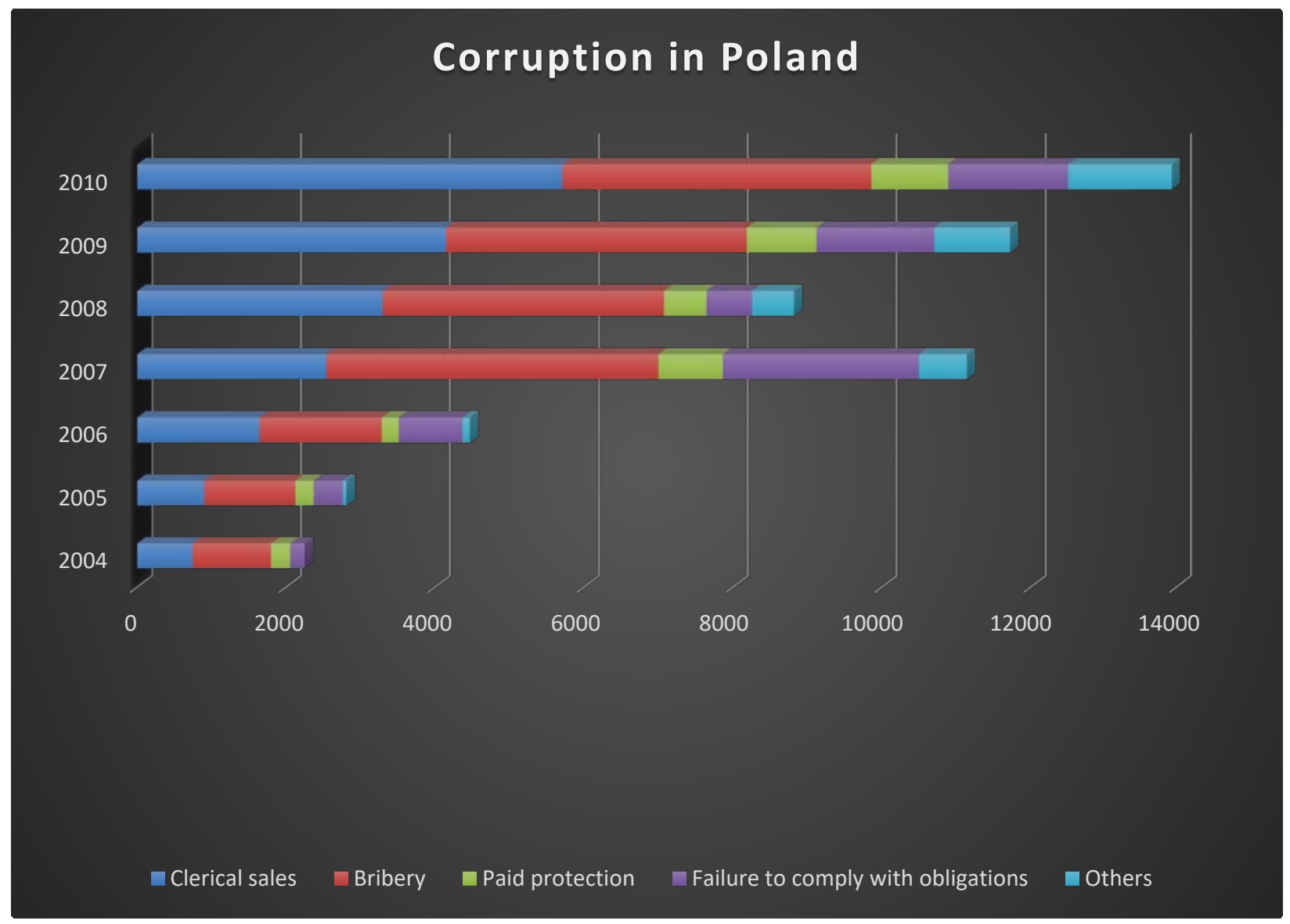

\section{Chart 1. [http://i.wp.pl/a//f/jpeg/30458/infografika_wp_korupcja_ti_cba_640.jpeg]}

The foregoing chart proves that there are several major types of offences related to corruption, but the two most common are the corruptibility of officials (5713 of the cases in 2010) and bribery (4462 of the cases in 2007). Over a period of seven years (2004-2010), the frequency of the former offence increased six fold, and the latter four fold. What is more, the two other offences, paid favouritism, failure to meet duties/abuse of duties were also on the rise (their levels increased three and thirteen times respectively). Subsequently, it can be concluded that corruption continues to thrive in Poland. The statistics above prove this.

Due to the fact that the scale and form of corruption differs from state to state, depending on the level of their economic and social development, the section below presents a catalogue of activities which may contribute to the growth of corruption (Aernoudt, 2003). "The argument is that economic development in poor countries requires a significant reduction of corruption, stable property rights and a rule of law. These objectives are not just desirable in themselves; the good governance analysis tells us they are also necessary for development” (Khan \& Grey, 2011). 


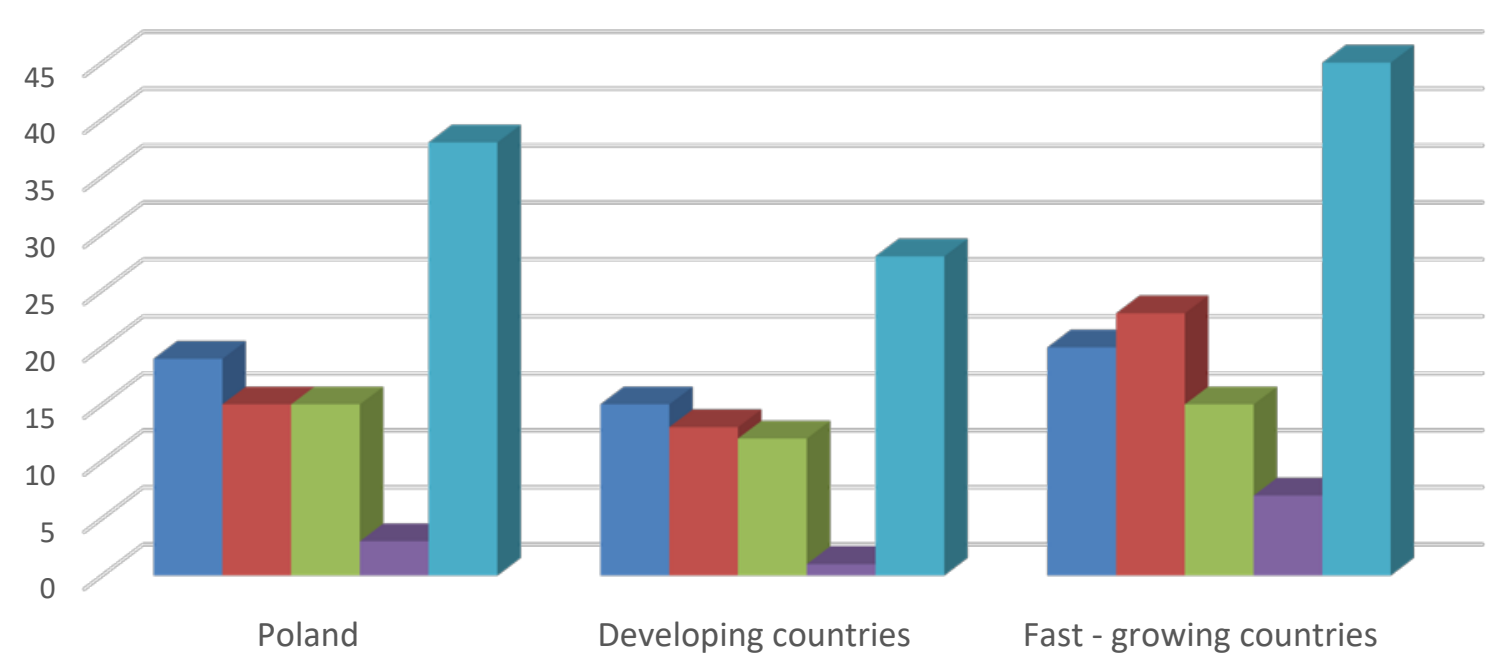

Giving gifts to obtain business relationships

- Offering benefits in order to gain business relationships

- Offering entertainment in order to gain business

- Falsification of data in financial statements

Ohers occurrence

Chart 2. [http://www.blog.ey.pl/audytsledczy/co-piaty-pracownik-w-polsce-wie-o-manipulacjachfinansowych-swojej-firmy-nasze-badanie]

As shown by statistical data, from the perspective of frequency of corruption and their type, Poland is placed between developed and developing countries. Although the scale of corruption clearly puts the country in the category of a developed state, 59\% of survey respondents believe that bribery and corruption are widespread in Poland (Gola, 2013). This result is better than in Eastern Europe (74\%), but it is much worse than in Western Europe (39\%). It is also worrisome that anti-corruption policies have been developed in only 38\% of Polish companies, and only one in five Polish enterprises (23\%) trains its employees in this respect. What is more, research has shown that Polish companies have quite a reluctant attitude towards the so-called whistle blowers (those who disclose wrongdoings). Moreover, only one in five companies (18\%) has introduced programs for reporting abuse and corruption.

Since corruption is present in various areas of professional and social activity, the section below presents the sectors which are most affected by bribery in Poland. 


\section{Frequency of corruption in Poland}

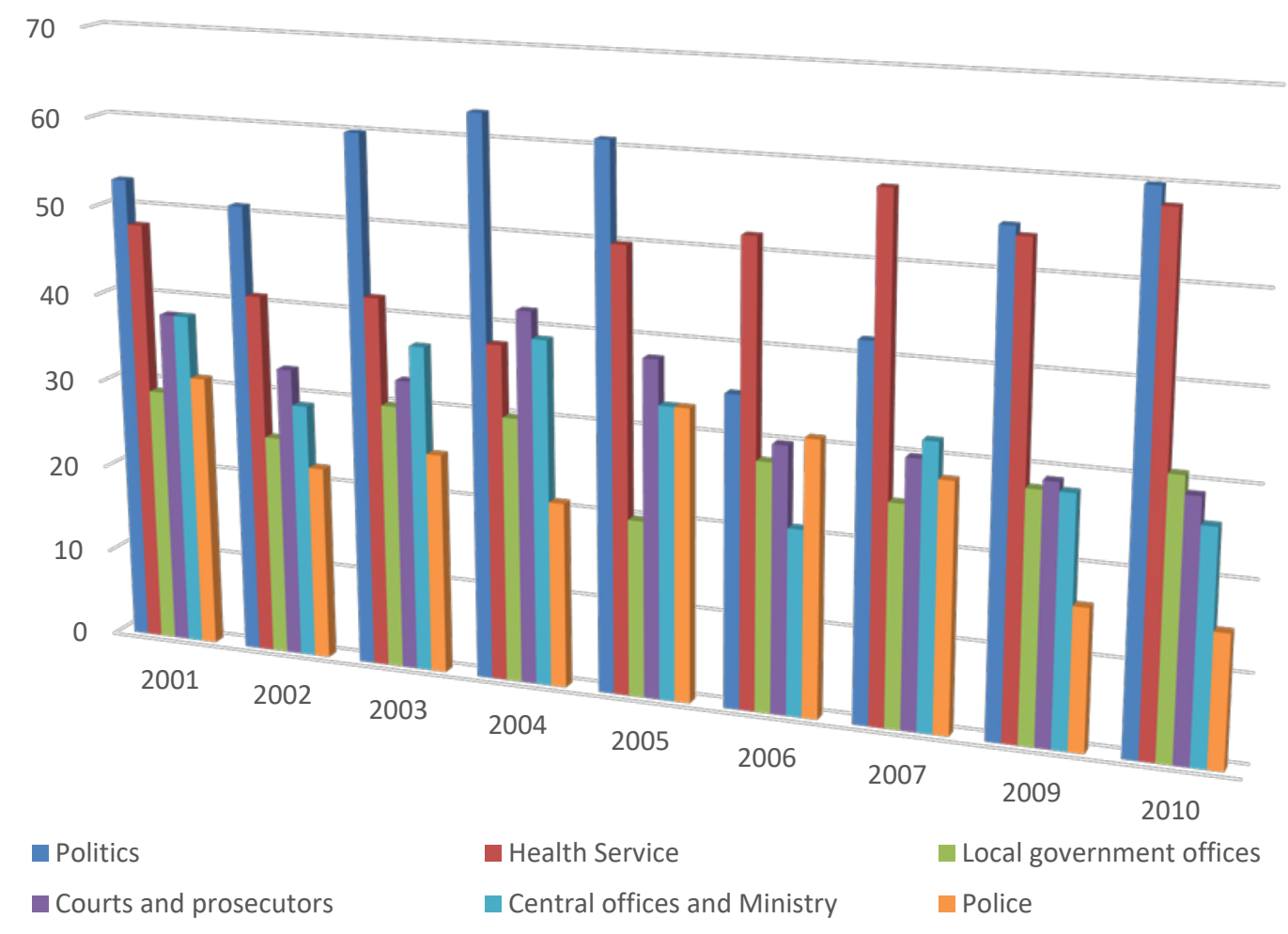

Chart 3. [https://www.google.pl/search?q=korupcja+w+polsce+statystyki+2015]

The statistics clearly show that the period of 2001-2010 contained the most frequent cases of bribery observed in two key areas: politics (especially in 2004) and health care (especially in 2007), respectively. The highest levels of corruption were found between the years 2001 and 2005 in the investigation and prosecution of authorities in the central authority and policing services.

In April 2013, a report entitled "The Good, the Bad and the Ugly. Controlling Corruption in the European Union” was published (Mangiu-Pippidi, 2013). The report was developed by the Berlin-based Hertie School of Governance and by the Bertelsmann Foundation and classified Poland, together with Bulgaria, the Czech Republic, Greece, Latvia, and Romania into one category of states (group D). This was characterised as the countries having the highest risk of corruption due to the low level of deterrents and high likelihood of occurrence. In the context of Poland, the authors noted that the advanced level of investments to GDP with poor anti-corruption control favours the fraudulent use of public funds (Mangiu-Pippidi, 2013). 


\section{Corruption vs. level of investments}

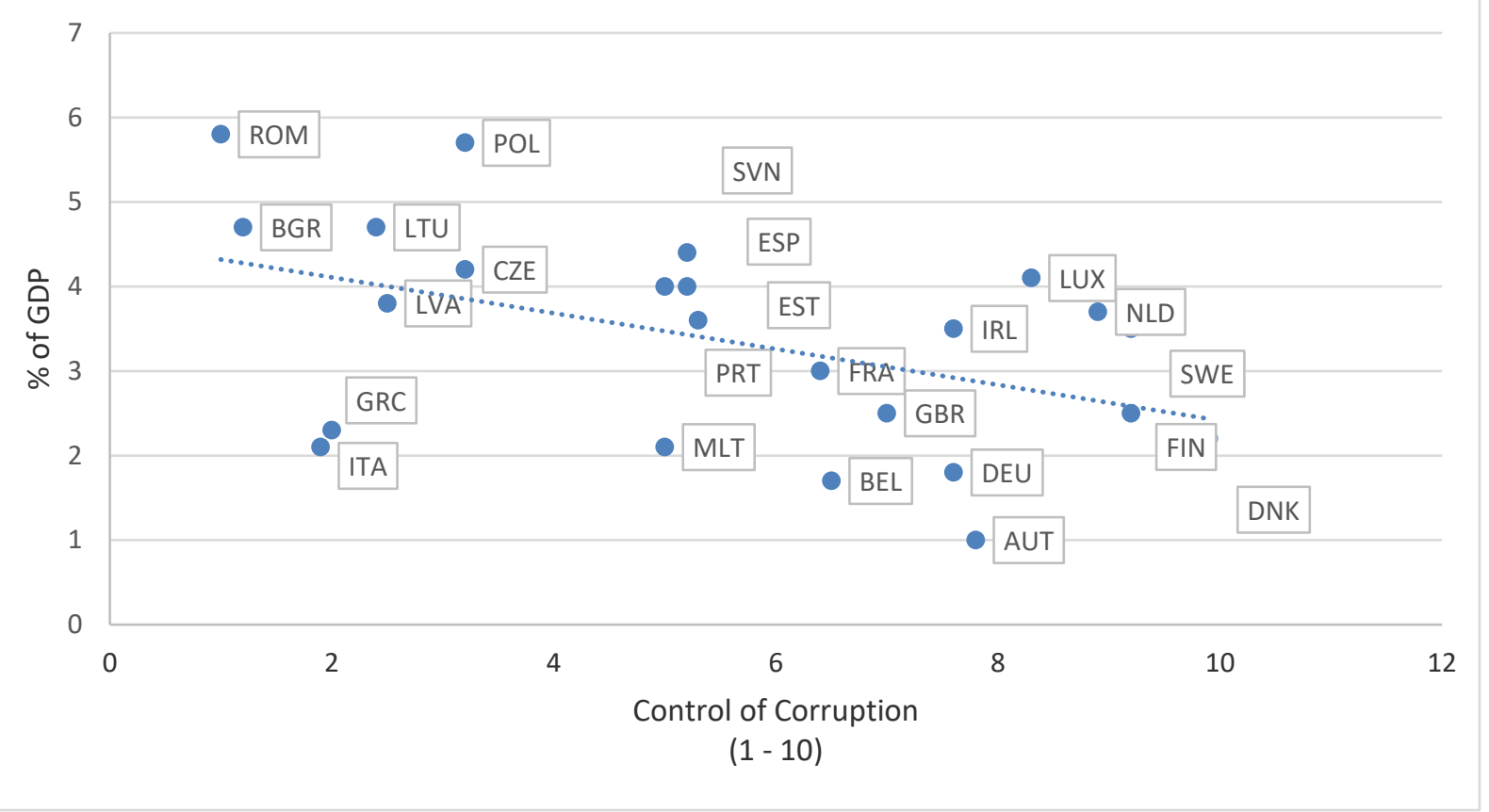

Chart 4. [https://cba.gov.pl/pl/newsy-serwisu-antykorup/2494,Raport-quotDobrzy-zli-i-paskudniquot.html]

One of the most important factors influencing the corruption level is the salaries offered in the public sector. From this perspective, the incomes of Polish clerks and officials are lagging behind other countries in Europe, which is a strong factor motivating the development of corruption. However, salary is not the only factor contributing to corruption. The report contains a list of other factors whose misfunctioning can result in fraud and abuses: investments to GDP ratio, e-government, mean average amount received within the cohesion policy, rules governing business activities, the existence of nongovernmental organisations, freedom of press, audit, and reporting abuse. Unfortunately, Poland did not rank high in any of these categories. One of the ratios used in the Report is the Bertelsmann Index (Bertelsmann Stiftung's Transformation Index or the BTI). BTI is designed to assess and analyse the quality of democracy in developing states or states undergoing transformation.

\section{Anti-Corruption Strategies}

Taking into account the development of various forms and manifestations of corruption, in September 2002 the Polish government adopted a program for preventing corruption referred to as the Anti-corruption Strategy. Tasks laid down in the Strategy were carried out over a period of two years. The report offered a comprehensive review of the program implementation, which was adopted by the Council of Ministers in October 2004. Since the elimination of corruption from social life must be seen as an ongoing process, the decision was made to go ahead with the 2nd stage of the Anti-corruption Strategy. The strategy assumed the implementation of legislative, organisational, and educational-informational measures, extended to new areas at risk of corruption. Moreover, tasks designed to monitor the effectiveness of the measures were introduced. The assumptions for the 2nd stage of the Strategy were based on the Supreme Audit Office and Internal Security Agency. The recommendations of the Group of States against the Corruption GRECO4 were prepared after the 2nd Round of evaluations carried out by 
the states. These documents were issued by the European Union and the Council of Europe on preventing corruption and the UN Anti-Corruption Convention (CBA, 2014).

- The strategic goals of the 2nd stage of the Anti-Corruption Strategy include:

- $\quad$ preventing corruption and the implementation of mechanisms that enable its effective prevention;

- coordinating activities aimed at enforcing compliance with anti-corruption laws;

- reducing social tolerance for corruption by increasing awareness and promoting appropriate model behaviours;

- developing transparent and citizen-friendly public administration structures tailored to the requirements of an open information society.

It must be emphasized that the scope of measures undertaken within the 2nd stage of the AntiCorruption Strategy was highly advanced. The areas of public life covered by anti-corruption measures included the economy, highest state authorities, public administration, judiciary and anti-corruption bodies, health care, public finance, education, culture, and mass media. "Corruption affects economic growth through many channels, one of them consisting of a modification of the structure of public expenditure in favor of specific types of spending. This distortion has not previously been clearly characterized.” (Croix \& Delavallade, 2009).

Taking into account the Transparency International research, one should conclude that the activities undertaken so far within the Strategy have generated moderately positive effects. The World Bank experts emphasize a major improvement of the situation in terms of corruption in Poland, which is not only attributed to growing social awareness but also the rules introduced as a result of joining the EU. However, there is no doubt that the Strategy has been the most successful when it comes to the effectiveness of prosecuting corruption. Currently, the government is carrying out the Anti-Corruption program for the period 2014-2019 (Mangiu-Pippidi, 2013).

\section{Discussion}

In the above analysis the question that arises is what is corruption and how is it perceived as one of the most serious pathologies?

In-depth analysis leads to the conclusion that corrupt persons sell their position, authority resulting from their position or influence, and thus the privileges they possess. There is also the opinion that in a rigid political system corruption can create an opening for those who are outside the circle of power, allowing them to informally influence different decisions. In the longer term, corruption hampers the functioning of the proper political structures and the real system of political institutions, sometimes even preventing them from arising and causing enormous losses in the economic and social development of a particular country.

Is corruption therefore a complex phenomenon? It is worth emphasizing that corruption is so multi-faceted that it cannot only be addressed by criminal and administrative law. In examining this problem of socio-economic life one should also refer to the findings of the other fields of knowledge, in particular ethics, philosophy, or economics. There is no doubt that in considering anti-corruption law one cannot deny the importance of axiology. Values should first determine the lawmaking process. Undoubtedly, dialogue between economics and ethics is needed.

In the context of corruption, what is the issue of taking positions in public administration and the issue of capital formation? 
Proper selection of employees is one of the most important elements on which the proper functioning of each institution depends. It may have a positive impact on the economy in developing countries. It should be borne in mind that corruption may be enhanced by the organization of the public administration, which, with its degree of complexity and bureaucratization, will force its citizens to seek paid protection, networks, and bribes.

\section{Conclusion}

Corruption is one of the most complex economic pathologies not only in Poland but worldwide. Whenever corruption comes into play, it weakens the state, destabilizing specific sectors of the economy and politics. Factors which foster corruption include the lack of transparency of a state, uncertainty, a deficit of explicit criteria for the performance of administrative tasks, failure to apply the principles of openness and transparency in administration, a deficit of accountability among public officers, and a weak civil service. Unfortunately, the statistics show that even the most complex anti-corruption strategies (Anti-corruption strategy 1, 2002-2004, Anti-corruption strategy 2, 2005-2009) fail to deliver expected results, as corruption remains a highly dangerous phenomenon and its prevalence has hardly been reduced. In view of the data discussed above and the awareness of corruption-related threats and persistent economic decline in Poland, it seems necessary to define new, more effective tools aimed at eradicating corruption. As shown by research, corruption may be considered ubiquitous, as it exists even in developed countries (chart 2), which means that it is impossible to eliminate it completely. In this context, it is even more pressing to take measures aimed at significantly reducing corruption in Poland.

The complexity of contemporary public administration requires extensive and transparent administrative and legal preventive measures. Establishment of such a system and ensuring its effective operation should be perceived as one of the foundations of a modern law-governed democratic state. Such systems should guarantee practical application of the principle of the legitimacy of the administration's operations, and citizens' trust in the state. The system should encompass virtually every sphere of public administration. Administrative and legal measures aimed at preventing corruption should help to increase social control over the exercising of public authority, and contribute to building a civic society based on democratic mechanisms and a social market economy model.

The omnipresence of corruption, its persistence, and degenerating impact on the functioning of the state's structures, public institutions, and interpersonal relations necessitates remedies. Due to the scale of complexity of this pathology in social life, the development of anti-corruption legal instruments in broadly understood public law, or even in some areas of private law, seems inevitable. There is no doubt that the major role in preventing and fighting corruption in terms of normative acts is played by public law. Certain anti-corruption mechanisms have been developed in criminal and administrative law. The specific nature of anti-corruption provisions in administrative law consists of a focus on prevention of corruption, while criminal law is preoccupied mainly with penalization of corrupt acts. Hence, it is a tool for fighting and preventing this crime in inasmuch as the threat of criminal liability can discourage a person from such behaviours. The two fields of public law mentioned above complement each other, forming a legal system of anti-corruption tools. This means that the legal measures provided for in administrative and criminal law, aimed at preventing and penalising corruption should be closely aligned with each other.

Undoubtedly, legislation, penalization, and transparency of actions of public officers are very important in preventing corruption. The importance of acts of international law which often increase detectability of corrupt practices and harmonize domestic regulations in the fight against corruption cannot be overestimated. The key role is played by the 2003 UN Convention Against Corruption. It is intended to support and reinforce measures aimed at the effective and successful prevention of and fight 
against corruption as well as broadly understood international cooperation. The Convention also refers to promoting responsible public interest and public property management. Most importantly, the documents address the problem of corruption in a comprehensive and thorough manner. They don't just specify a list of penalised behaviours, but also deal with the causes and consequences of bribery. Signatories of this international agreement are obliged to develop and implement or maintain effective, coordinated anti-corruption policies that promote the participation of society and reflect the principles of the rule of law, proper management of public affairs and public property, integrity, transparency, and accountability. They are obliged to make efforts aimed at establishing and supporting effective corruption prevention practices.

To conclude this discussion on corruption, it should be noted that unfortunately various efforts to prevent this pathological behaviour do not lead to the elimination of corruption from the economic systems of individual states. Depending on the developmental level of political structures and the economy, and on the economic growth rate, forms of corruption prevention evolve from less developed strategies to more advanced practices. Nonetheless, it should be emphasised that all efforts made in this respect: economic, business, and legislative, can only lead to a decrease or minimisation of the occurrence of individual behaviours encouraging corrupt practices, yet, they will never help to eliminate the pathology constituting very dangerous breaches and attacks not only on the economic safety of individual countries, but also on the proper operation of their public bodies and transparency of officials' activities. However, the absence of any action to prevent corruption, particularly in individual spheres of state life, may contribute to strengthening the belief that fighting it is impossible. Therefore, it is necessary to make efforts to show that society will not tolerate any suspicious behaviours that would lead to corrupting the proper functioning of any of the dimensions of the respective economies.

\section{References}

Aernoudt, R. (2003). Corruption à foison (p. 25-26). Editions L’Harmattan : Paris.

Aidt, T.S. (2009). Corruption, institutions, and economic development. Oxford Review of Economic Policy, 25(2), 271-291.

Anderson, J. H., Hellman, J., Jones, G. P., Moore, B., Muller, H. W., Pradhan, S., Ryterman, R. S. \& Sutch, M. H., (2000). Anticorruption in transition : a contribution to the policy debate (Report No. 20925). Retrieved from The World Bank website: http://documents.worldbank.org/curated/ en/825161468029662026/Anticorruption-in-transition-a-contribution-to-the-policy-debate

CBA, (2014). Strategia Antykorupcyjna II etap wdrażania. Retrieved from http://www.antykorupcja.gov.pl/ak/strategia-antykorupcyj/2515,Strategia Antykorupcyjna-IIetap-wdrazania.html

Central Act - Corruption Bureau Act, Dz. U. [Journal of Laws] of 2006, no. 104, item 708, as amended. Warsaw.

De la Croix, D., \& Delavallade, C. (2009). Growth, public investment and corruption with failing institutions. Economics of Governance, 10, 187.

Czaputowicz, J. (2008). Korupcja w Polsce Przegląd obszarów priorytetowych i propozycji przeciwdziałania zjawisku, World Bank report, Warsaw 2000, quoted after: J. Czaputowicz, Standardy etyczne administracji publicznej (in:) Administracja publiczna. Wyzwania w dobie integracji europejskiej, (pp. 366). Warsaw.

Czubek, G., Kopińska, G., Sawicki, A., \& Wojciechowska-Nowak, A. (2010). Zasady tworzenia i wdrażania strategii antykorupcyjnej dla Polski, Fundacja im. Stefana Batorego,15-16. Warsaw. 
Dunphy, H. (1999, August 21) IMF, World Bank Link Aid to “Good Governance”. Washington Times.

Garus-Ryba, J. (2000). Prawnokarne środki walki z korupcją w świetle polskiego kodeksu karnegoi wybranych konwencji międzynarodowych. In Dostosowanie polskiego prawa do wymogów Unii Europejskiej cz. 2. Zeszyty Naukowe Kolegium Nauk Społecznych i Administracji Politechniki Warszawskiej, (p. 101). Warsaw.

Gola, J. (2013). La corruption dans l'approche économique. Ekonomia - Wrocław Economic Review, 19(3), 21-27. Wroclaw.

Gola, J. \& Olszewski, B. (2010). Sposoby rozstrzygania konfliktów na tle udzielania ograniczonej liczby koncesji In: M. Tabernacka \& R. Raszewska-Skałecka., Płaszczyzny konfliktów w administracji publicznej. Warsaw.

Horubski, K. (2007). Instrumentalne kryteria oceny ofert. Przeglad Prawa Publicznego, n 11, 22. Warsaw.

Khan, M. H., \& Gray, H. (2011). State weakness in developing countries and strategies of institutional reform - Operational Implications for Anti-Corruption Policy and A case-study of Tanzania. Department for International Development.

Kojder, A. (2002). Korupcja i poczucie moralne Polaków. In Kondycja moralna społeczeństwa polskiego (pp. 202-242). Cracow.

Koryś, P. (2006). Korupcja a zaufanie, czyli społeczne konsekwencje korupcji. In M. Tymiński \& P. Koryś, Oblicza korupcji. Zjawisko, skutki, metody przeciwdziałania (pp. 66-68). Warsaw.

Kurczewski, J. (2001) Korupcja rządów. Warsaw.

Kurczewski, J. \& Łaciak, B. (2000). Korupcja w życiu społecznym. Warsaw.

Mapa Korupcji. (2010). Stan korupcji w Polsce na podstawie danych statystycznych przekazanych przez stużby i organy państwowe za lata 2004-2009. Retrieved from http://www.cba.gov.pl/ftp/ zdjecia/Mapa korupcji.pdf

Mapa Korupcji, CBA (2010). Jak walczyć z korupcją? Zasady tworzenia i wdrażania strategii antykorupcyjnej dla Polski”, Fundacja im. Stefana Batorego, (p.15). Warsaw.

Mangiu-Pippidi, A. (2013). The Good, the Bad and the Ugly: Controlling Corruption in the European Union. Retrieved from http://anticorrp.eu/publications/the-good-the-bad-and-the-uglycontrolling-corruption-in-the-european-union-2

Nowak, C. (2009) Korupcja w polskim prawie. Warsaw.

O’Donnell, M. (2006). Post-conflict Corruption: A Rule of Law Agenda? Retrieved from https://pdfs.semanticscholar.org/0e0c/6371f286df9e8efd3ad27c1f0056d9dc94ee.pdf?.ga=2.1955 $\underline{68236.1900674442 .1559171488-1564725536.1559171488}$

Płoskonka, J. (2008). Korupcja. Zagrożenia i metody jej zwalczania. In J. Czaputowicz, Administracja publiczna. Wyzwania w dobie integracji europejskiej (pp. 440-442). Warsaw.

Raport Dobrzy, źli i paskudni. (2013). Wydziat Informacji i Edukacji Antykorupcyjnej CBA. Retrieved from https://cba.gov.pl/pl/newsy-serwisu-antykorup/2494,Raport-quotDobrzy-zli-ipaskudniquot.html

Rose-Ackerman, S. (2001). Korupcja i rzady. Przyczyny, skutki i drogi reform. Warsaw.

Rose-Ackermann, S. (2004). The Challenge of Poor Governance and Corruption. Retrieved from https://www.copenhagenconsensus.com/sites/default/files/cp-corruptionfinished.pdf

Rosik, P. (2016). Wskaźniki korupcji nie zwalcza. Retrieved from https://www.obserwatorfinansowy.pl/ tematyka/makroekonomia/wskazniki-korupcji-nie-zwalcza 
Siwik, Z. (2009). Opinia o projekcie ustawy o Centralnym Biurze Antykorupcyjnym, Cz. Szczegółowa 2, 1-2. Warsaw.

Srebro, B. (2004). Ochrona interesów finansowych. Warsaw.

Szydło, M. (2005). Swoboda działalności gospodarczej. Warsaw.

Tarchalski, K. (2000). Korupcja i przywilej. Zarys teorii i praktyki. Warsaw.

Tymiński, M. (2006) Normy etyczne-konflikt interesów-korupcja. In M. Tymiński \& P. Koryś, Oblicza korupcji: zjawisko, skutki i metody przeciwdziatania (p. 54-55). Warsaw.

Urbańska, A. (2003). Korupcja-ujęcie ogólne In J. Pitera (ed.) Mapa korupcji w Polsce. Transparency International (p. 27). Warsaw.

Witalis, M. (2013). Biznes na polu minowym? Nadużycia w czasach zwiększonego Ryzyka. Badanie Nadużyć Gospodarczych. Europa, Bliski Wschód, Indie i Afryka (EMEIA). Retrieved from http://www.blog.ey.pl/audytsledczy/wp-content/uploads/2013/05/

Badanie_Naduzyc_Gospodarczych_2013_prezentacja.pdf

Zarządzenie nr 15/16 Szefa Centralnego Biura Antykorupcyjnego z dnia 7 czerwca 2016 r. zmieniające zarządzenie w sprawie sposobu realizacji zadań wynikających z Rządowego Programu Przeciwdziałania Korupcji na lata 2014-2019. (2016). Warsaw. 